\title{
The Interaction between Stock Market and Futures Market
}

\author{
De-Yu CHEN \\ Guangzhou College of commerce
}

\begin{abstract}
This paper from the transaction of commodity futures market and the stock market prove overall linkage of two markets, the futures market Mandarin commodity futures index and stock market index for the total sample, using the correlation test, unit root test, cointegration test and Granger causality test, empirical study of the price of the two markets the linkage relationship, can be seen from China's futures market and the stock market funds did not price obvious linkage, Wenhua commodity futures index trend does not lead the trend of the index.
\end{abstract}

\section{Keywords-futures market stock market price linkage}

The stock market is the most exposed to investors, but also the market research every day. If you always put your eyes on the stock market, there are inevitably limitations. From the various capital markets and the relationship between the impacts of the stock market, the vision will be greatly expanded, clarity will be greatly improved. At present, understand that not many investors see amphibious linkage. At present, the domestic futures market is far less than the number of stocks on the stock market investment group, we are not unfamiliar, but the futures market is not familiar with the comprehensive view and the link between the more obvious value and the specific strategy.

\section{AN EMPIRICAL ANALYSIS OF THE RELATIONSHIP BETWEEN FUTURES MARKET AND STOCK MARKET PRICE}

Both the futures market and the stock market belong to the capital market. Under the background of the big economy, these two markets have a mutual linkage. Commodity futures prices reflect the future price of goods, the price trend is actually reflected in people's expectations, and the futures price is due to expectations, so we can find the future price of the spot. An example of agricultural products futures market, with agricultural products from sowing to harvest and sowing, completion of a production (supply) - demand - production (supply) the expected cycle, at the same time, analysis of the specific movements in commodity prices in this process, according to the seasonal changes of downstream industry consumption the time to judge the conditions of supply and demand in each period. The price of the stock, in fact, reflects the investors' expectations of the profitability of listed companies. People often choose to buy a stock that has the company's growth, and in the analysis of the transaction, usually attention can measure the profitability of the company's earnings per share (EPS) and earnings (PE) index, and predict the future of the EPS and PE of the two values, and then infer the next two years the price can reach much. The concept of the stock market, such as asset restructuring, asset injection, the overall listing, etc., is the future profitability of listed companies is expected. In addition, the stock market, the major issues of listed companies, the monthly, quarterly and annual reports of attention is also a kind of expectations, with the futures market futures of all major government reports, weekly, monthly report on the supply and demand of different approaches but equally satisfactory results.

At present, the long-term investment in the stock market and futures market investors come to the point of view: the stock market crash to the commodity futures market has a negative impact. This view shows a strong correlation between the stock market and commodity futures markets are related, because from a macro point of view, the main influence factors of stock market and futures market is the same: the development of the country and the global economy; government regulation. GDP steady growth, good momentum of economic development for the capital market is the biggest positive, the stock market is a barometer of economic development, investors will be willing to invest in the virtual economy, and stock prices continue to rise. At the same time, along with the economic growth, the demand for commodities in the amplification, the value of commodity is constantly increasing, the value of a commodity and its price to avoid the risk of accreditation requirements will promote the commodity trading, and to reflect the value of the goods found on the futures market. As for monetary policy, such as the deposit and lending rates and deposit reserve rate adjustment, liquidity control, can affect the mentality of investors, participation and influence of the stock market and futures market funds; fiscal policy, such as the adjustment of government investment spending and taxes, which of the listed companies of the industry and the company in itself, a positive or negative impact on the downstream industry chain and commodity industries, thereby affecting the supply and consumption situation of listed companies profitability and goods, the final transfer to the stock price and futures price.

\section{QUANTITATIVE ANALYSIS OF THE RELATIONSHIP BETWEEN FUTURES MARKET AND STOCK MARKET}

In order to study the relationship between the stock market and futures market in China, in this paper selected during the January 2016 -2017 year in January the Shanghai index week closing price (SZ001) and Mandarin 
commodity index $(\mathrm{QH})$ of the week's closing price as the research object. Because there is not yet a more authoritative commodity index, so that the Mandarin commodity index represents the overall trend of commodity futures market. The above two time series data are processed by the statistical software Eviews5.0, as shown in figure:

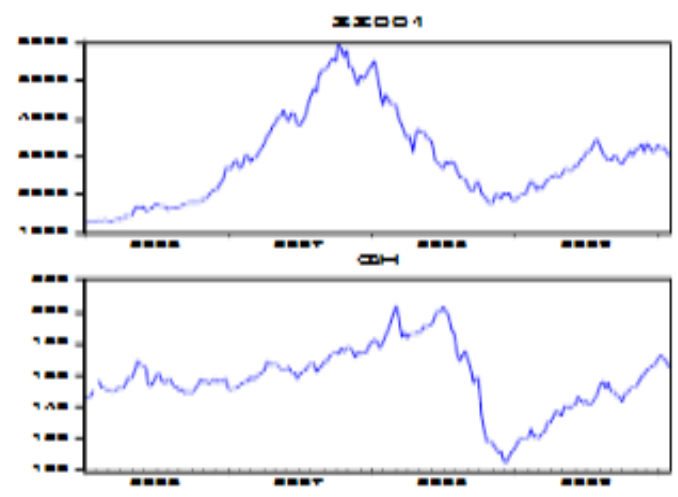

there is a certain correlation between the Shanghai index and the China Commodity Futures Index in the period from January 2016 to January 2017. The correlation coefficient between them can be obtained by analyzing the correlation coefficient matrix of Eviews5.0 0.53. It is found that both $\mathrm{QH}$ and SZ001 are non-stationary sequences by ADF stationary test, but their first order difference is a stationary sequence, which is I (1) process. Then through the Granger causality test, we find that the rising index has a strong relationship to the futures commodity index.

from the SZ001 new information on the $\mathrm{QH}$ is positively significant relationships between them, with the passage of time, this effect is more obvious. In the second half of the graph, SZ001 has a strong response to its own standard deviation, and the price has increased by about 135 points. SZ001 short-term response from the new QH is not obvious, the long-term impact is minimal.

\section{THE OPPORTUNITY TO LOOK AT THE STOCK MARKET THROUGH COMMODITY FUTURES.}

It is difficult for investors to determine the risk is huge or when the opportunity is huge, might as well put their eyes on commodity futures up, especially when the subject of investment is related to the non-ferrous metal plate, but also has the actual combat power.

If investors understand the trend of commodity futures to contact the judge, the idea is clear. It is easy to find that this is the rise of the star breakthrough state, the last trading day of a new attitude, indicating that there should be room for the future.

Commodity futures is often a leading indicator of the role in the two cities under the background of increasingly close linkage, from the State commodity futures at the time point of view, the probability of the corresponding stage of Jiangxi copper was at the top of the building is very low, the future still have a chance to complete a new high, and continue to come out of the wave line. The relationship between the two, it will be found that the views of some stocks will become clearer. Investors can use the commodity futures at the time of the state, the firm choose positions or opening strategy.

\section{CONCLUSION}

Futures price discovery function, that is, the general trend of futures prices will guide the spot price trend. However, according to the above analysis, we found that the trend of the Shanghai commodity futures index did not lead the trend of the Shanghai Composite Index in the modeling analysis of the Shanghai index and the Shanghai commodity futures index during the period of January 2016 -2017 in January. The main reason for this is that we have the following points:

1, the Mandarin commodity futures index failed to represent the entire commodity futures market scientifically and reasonably, the preparation of some defects.

2 , because our country has not yet introduced stock index futures, makes research on the linkage of the futures of stock market and the futures market and Shanghai stock index with Mandarin commodity index instead of stock index deviation.

3, China's stock market development more mature futures market, stock investment has become increasingly popular, but investors in the futures investment is still new, recently more and more investors in the futures market, these investors hold stock ideas to futures speculation, keep stock investment habits of futures, when the stock index rose does futures, when the index fell short of futures, then follow the index futures makes the phenomenon of It is often seen.

4, China's capital market is not perfect, not many varieties of investment, cannot be a variety of investment portfolio. At present, many institutional investors in order to increase the income, risk diversification, asset allocation and hedge only through the stock market and futures market, resulting in China's futures market and the stock market correlation relative to foreign developed capital market.

Many opportunities, in fact, bred in the commodity futures market and the linkage process between the stock market, the above is more about opportunities, risk judgments, and the truth is the same. Of course, the relationship between the two linkages is not absolute, it is necessary to specific analysis of specific issues, in general, the two cities are more violent fluctuations, and the relationship between the linkages is more prominent.

The close degree fluctuation of the two markets has risen to a new level, which is the current domestic investors (mainly institutional investors) view up to a new height of a great relationship, but also reflects Chinese capital market progress. China's commodity futures market is a relatively mature market, basically in line with international standards, but some specific rules a little different. Chinese commodity futures market is currently more follow the outer disk fluctuations, in order to study China's commodity futures and stock market linkage, vision also must be put in the foreign countries, and foreign influence of futures market volatility and exchange rate and other factors 
involved. And it will find that the world is a linkage of the world, many opportunities and risks are contained.

\section{REFERENCE}

[1] Chen Menggen. The growth of securities market and institutional change in transitional economy [J]. Journal of Dongbei University of Finance and Economics, 2017-3-10.

[2] King [2] fuck a fool operation. The stock market futures market panic China securities [N]. Amplification, 2016-2-2.

[3] Li Zhongqiu. Stock market plunge triggered industrial futures [N]. Shanghai securities news, 2017-3-13.

Note:This project is a periodical achievement of Guangzhou Guangdong commercial college electronic business construction project. File No. [2017]1, Guangdong Province Education Department, Guangdong Province, No., item No. TSZDXK201601" 